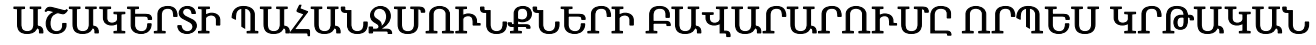

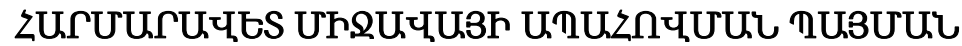

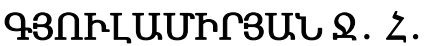

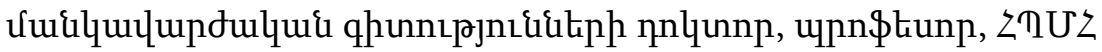

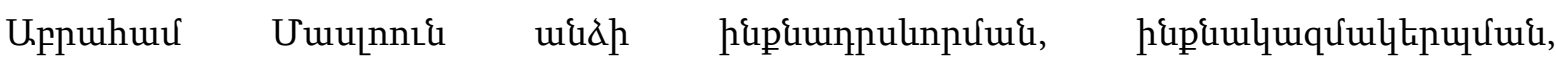

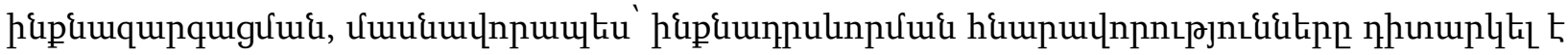

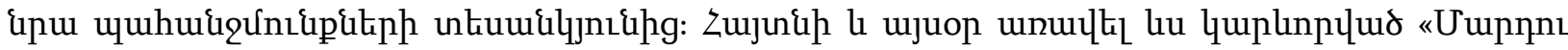

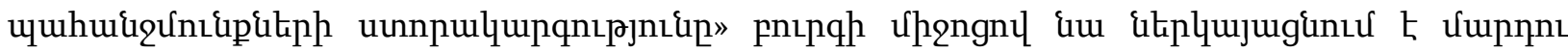

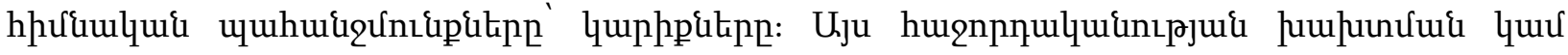

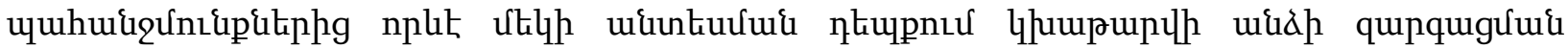

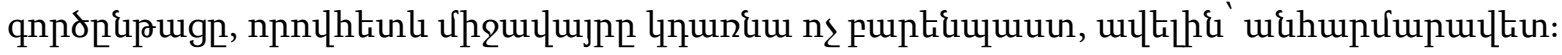

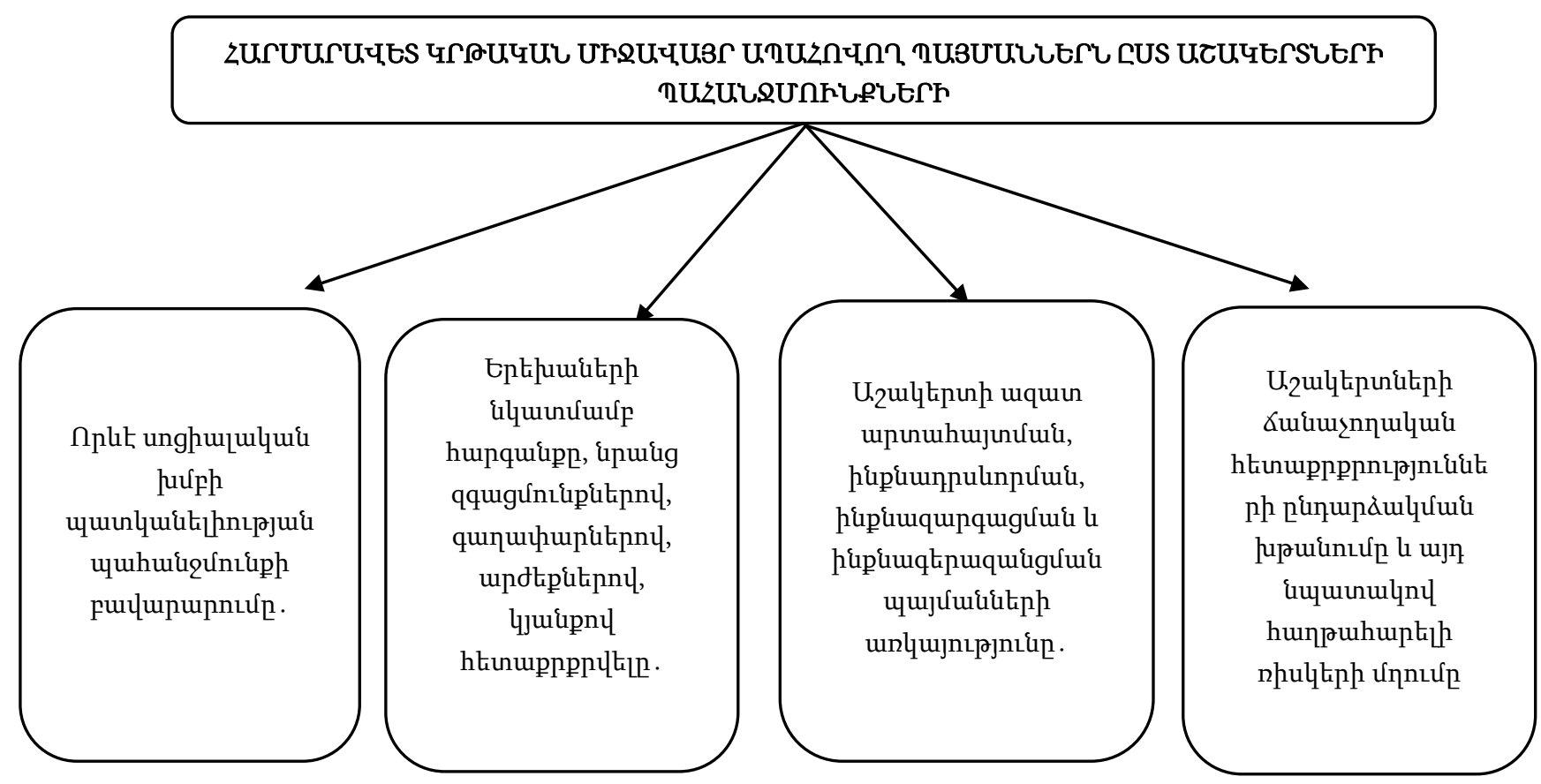

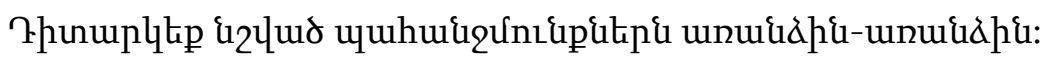

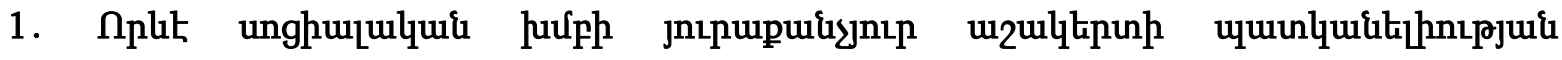

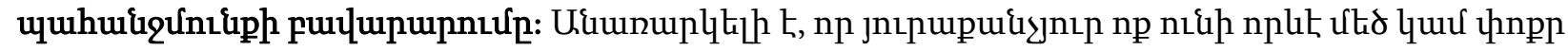

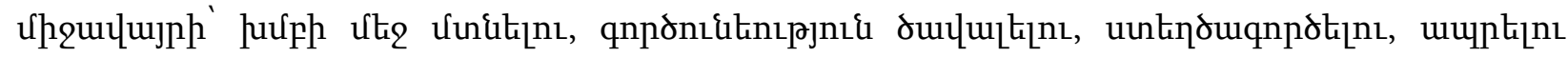

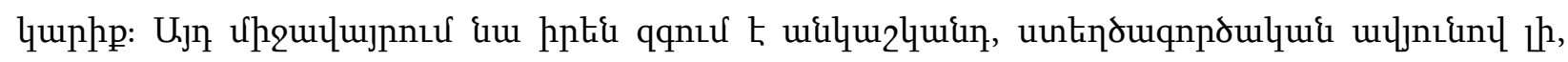




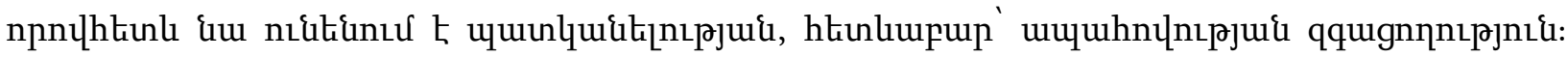

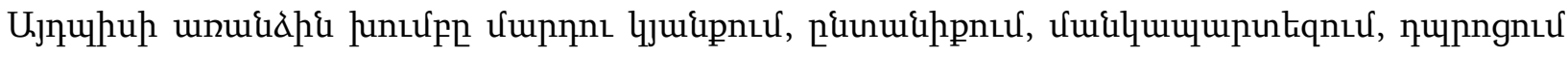

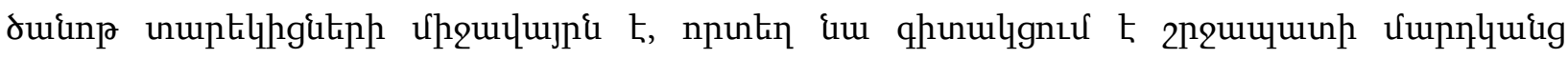

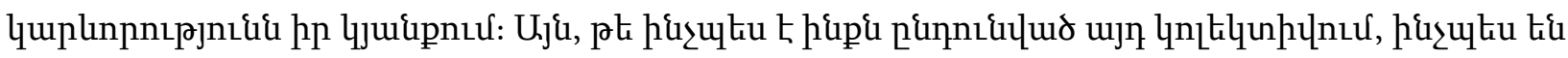

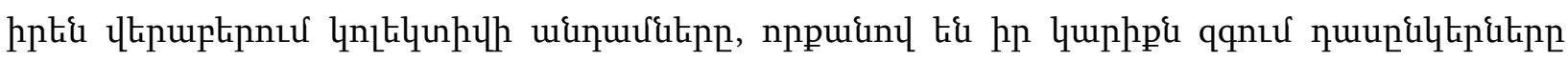

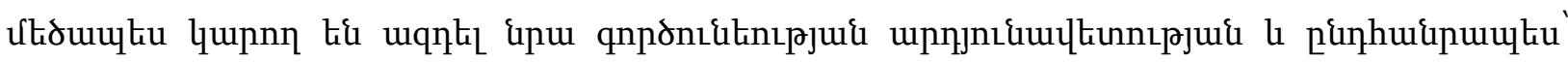

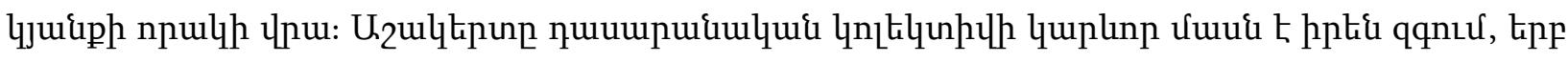

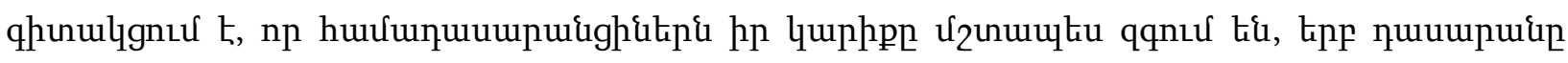

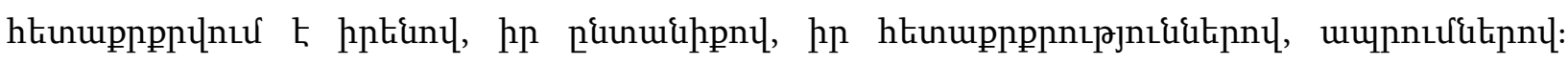

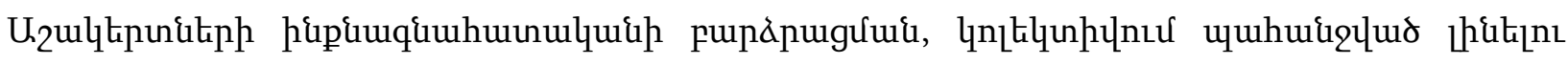

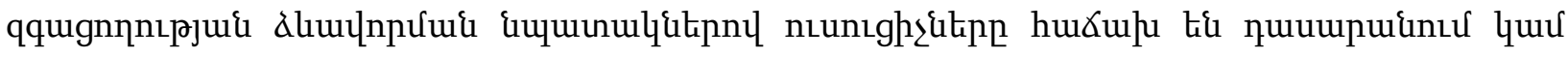

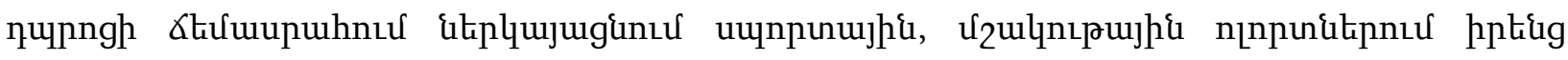

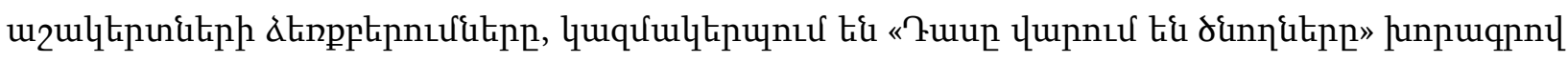

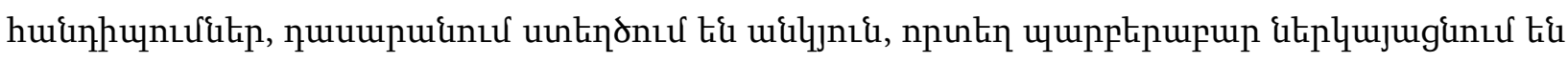

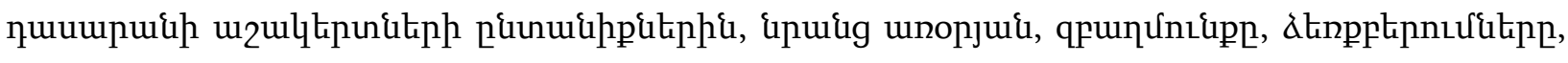

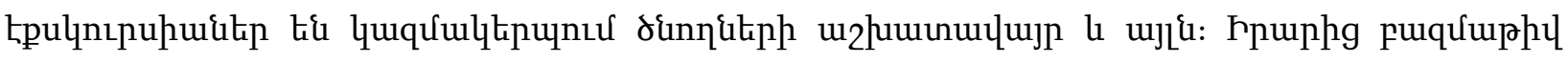

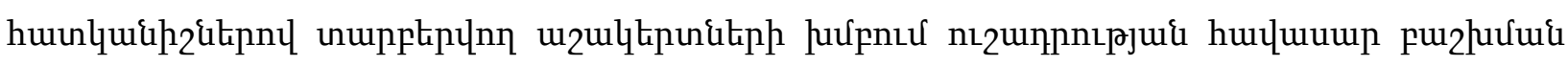

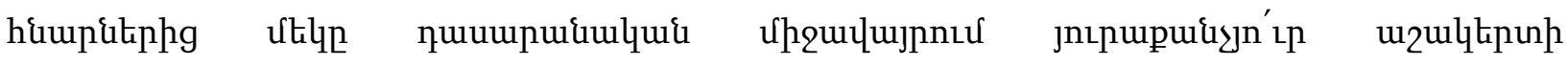

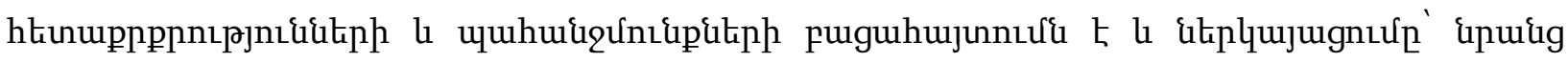

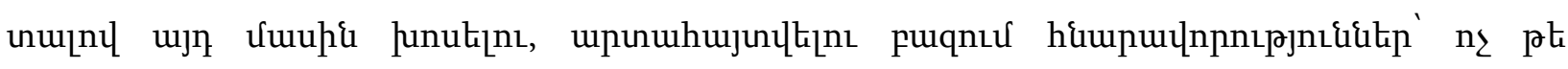

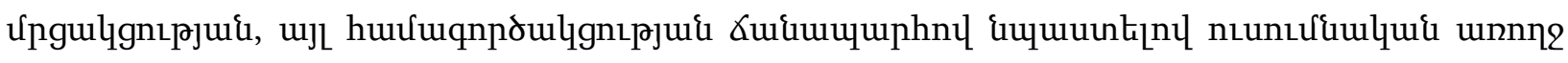

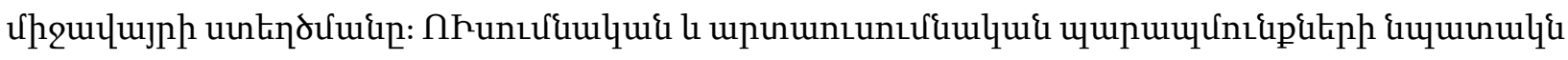

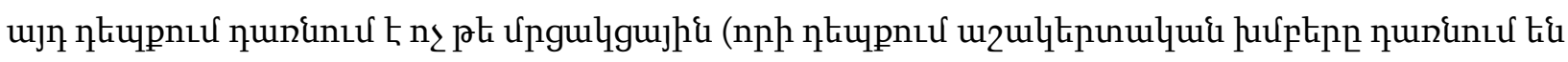

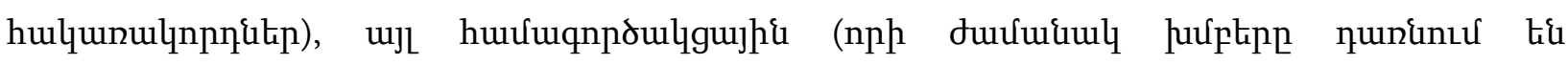

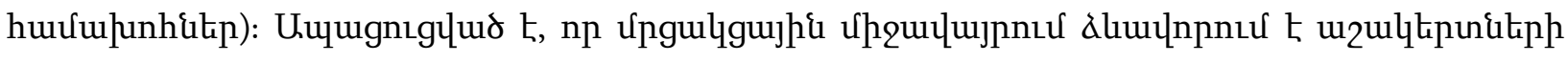

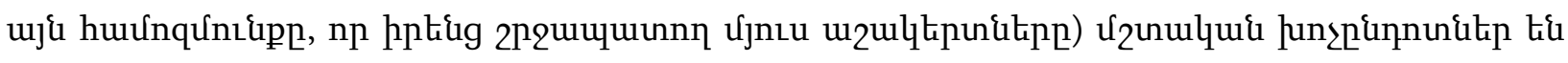

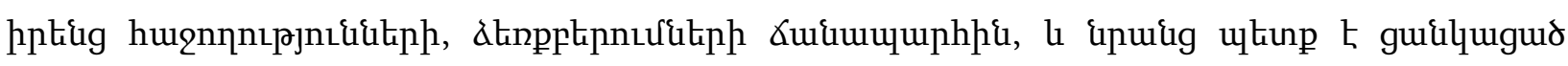

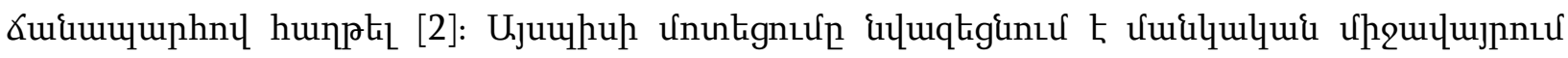

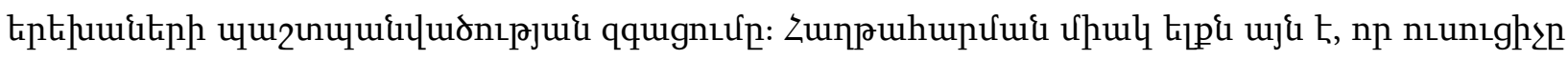

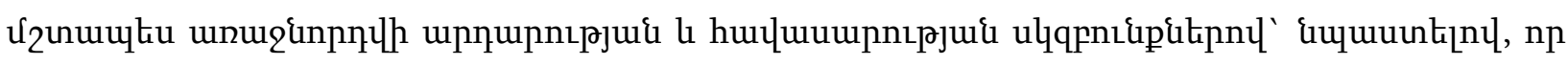

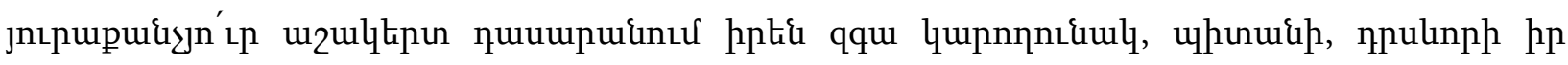

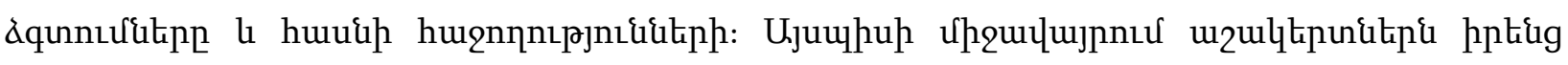

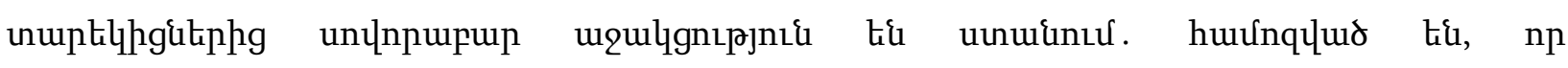




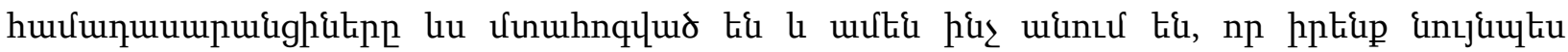

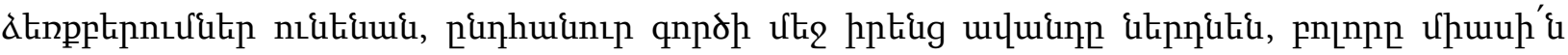

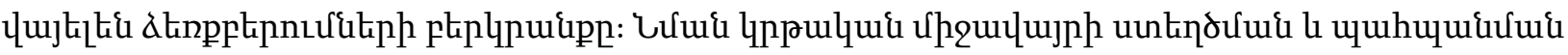

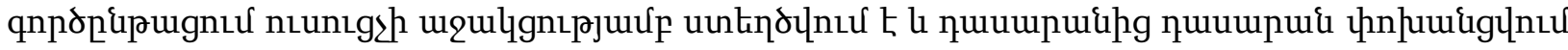

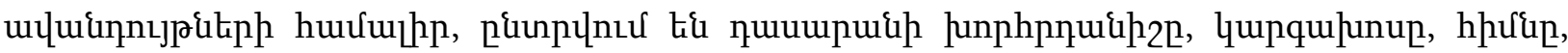

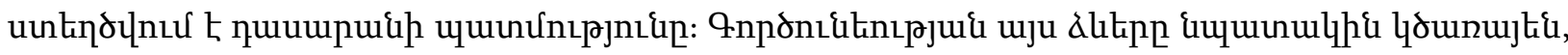

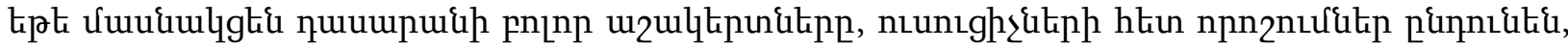

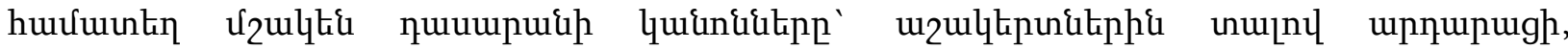

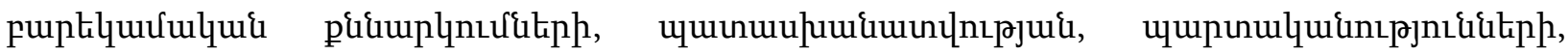

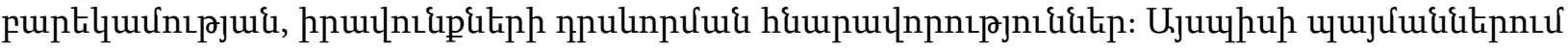

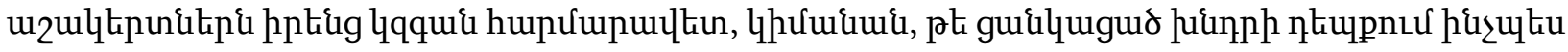

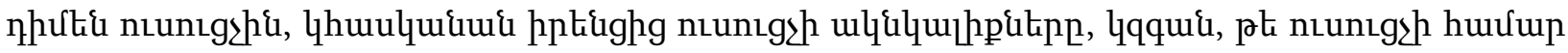

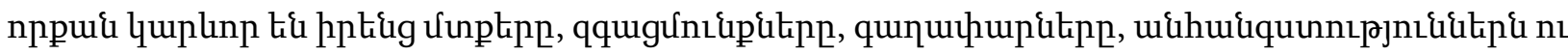

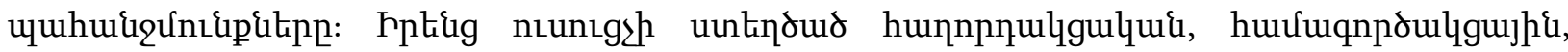

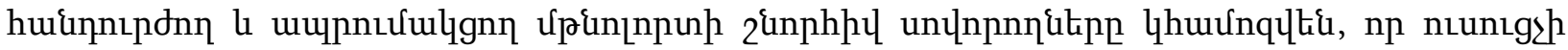

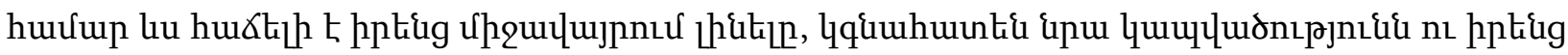

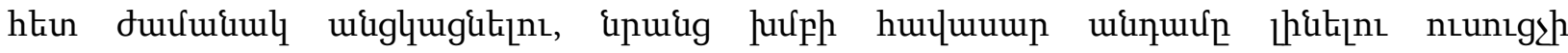

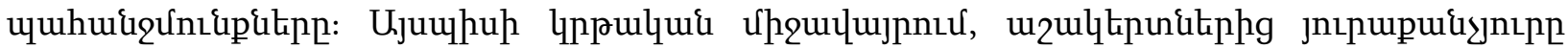

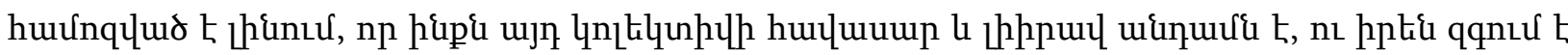
hupưupul|tin uuuwhnц:

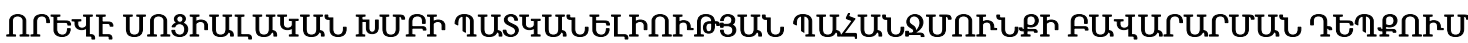

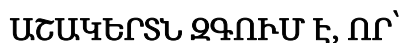

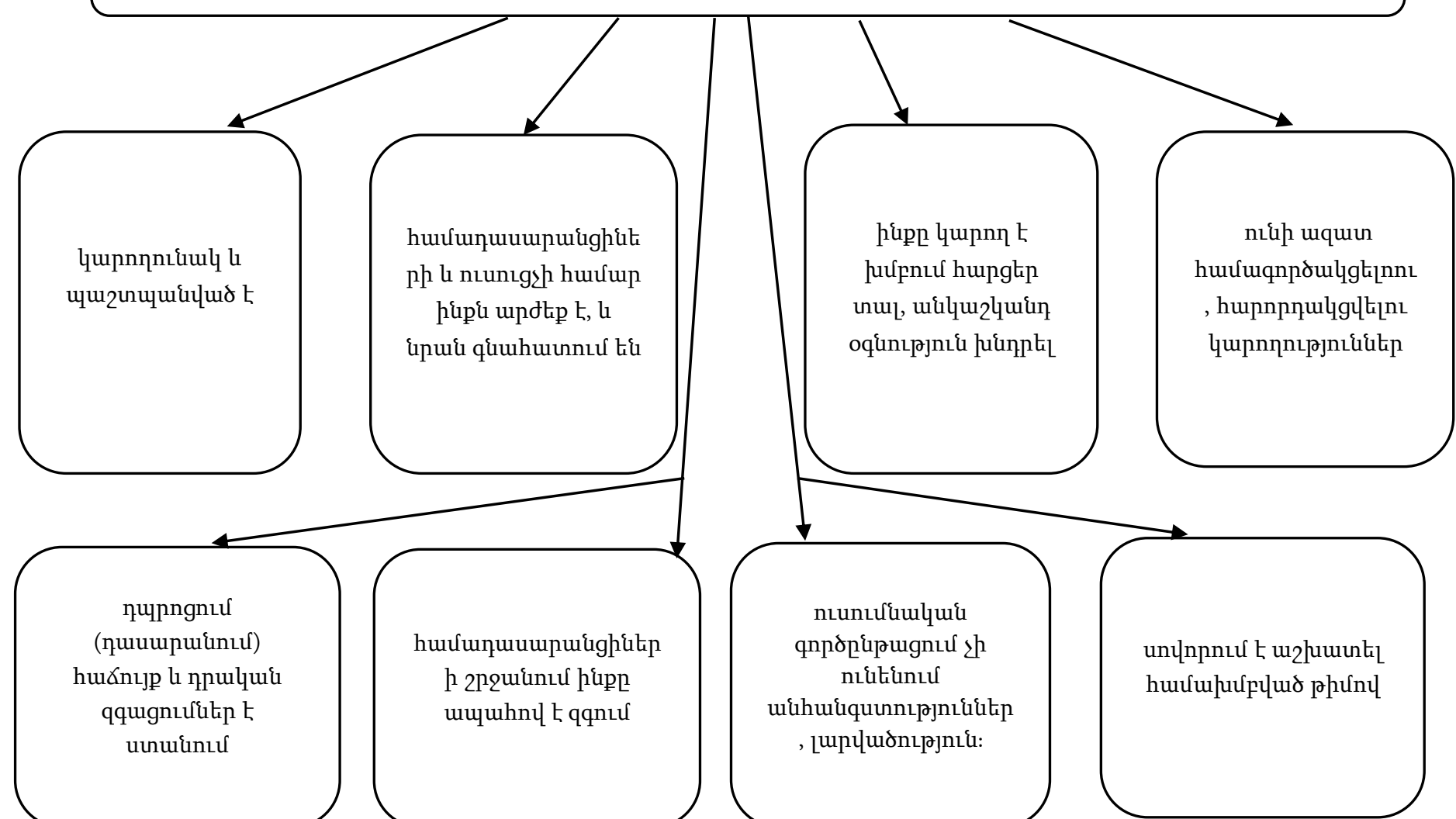




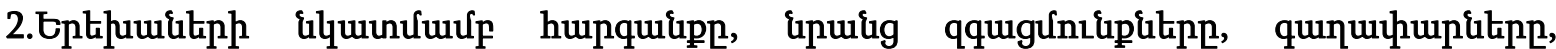

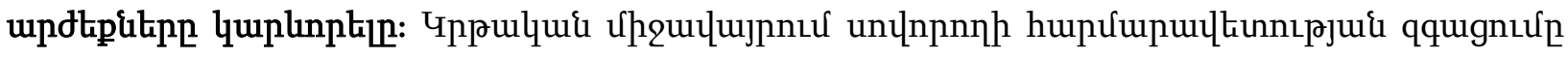

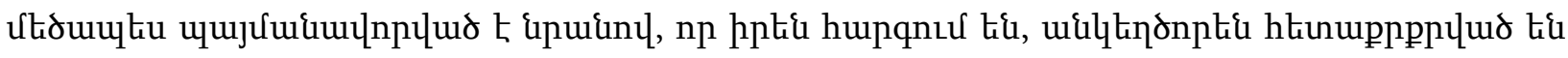

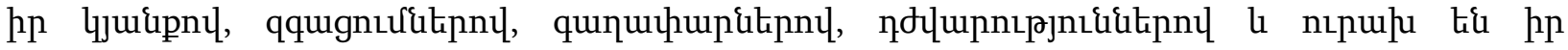

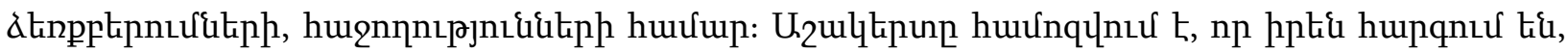

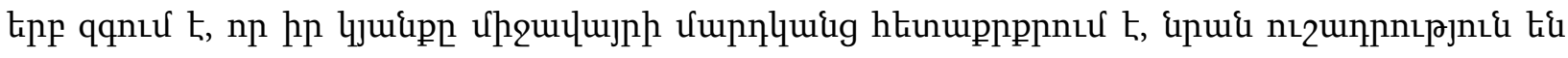

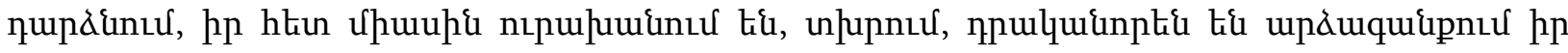

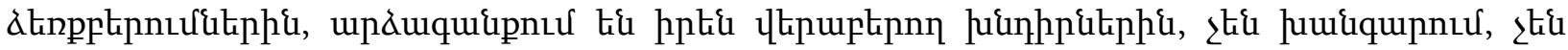

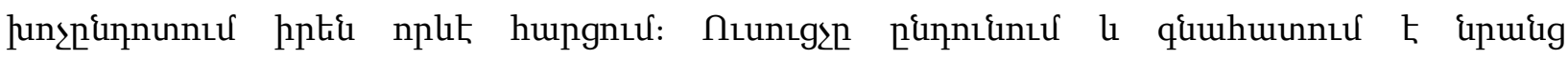

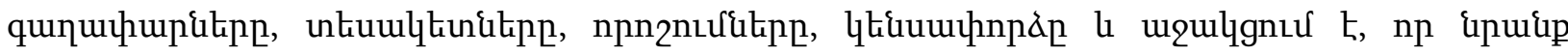

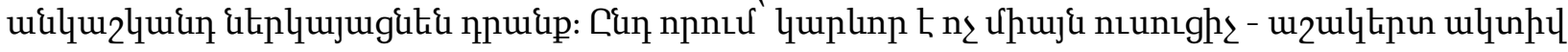

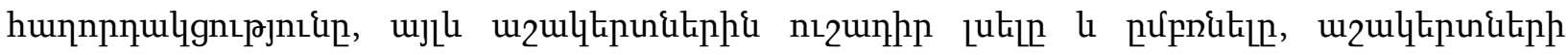

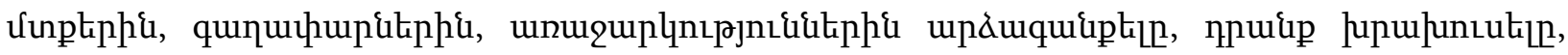

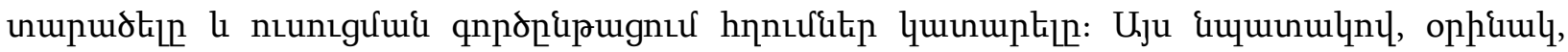

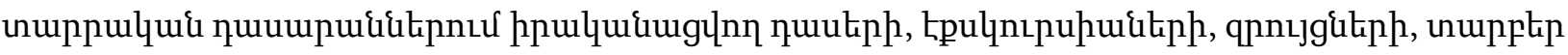

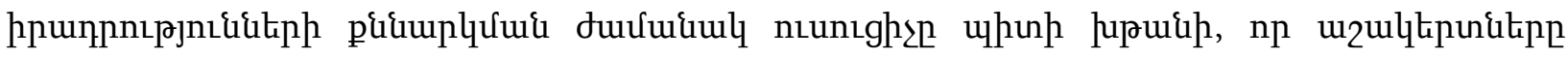

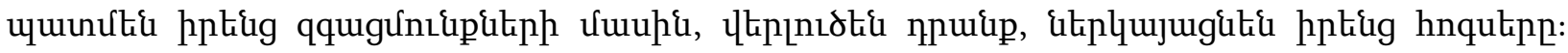

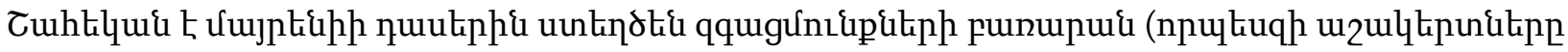

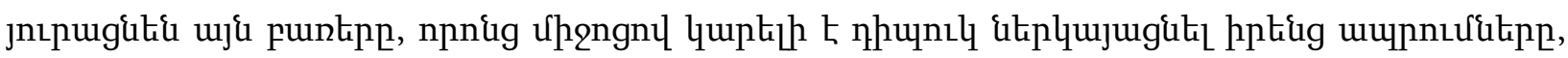

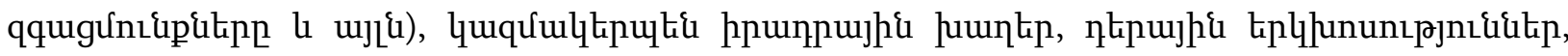

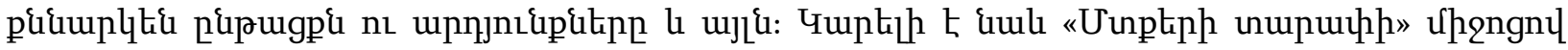

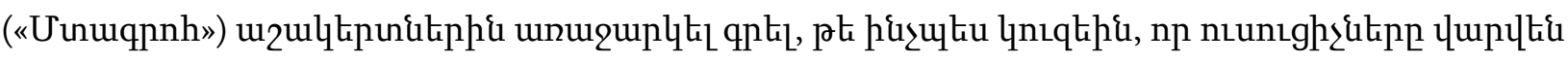

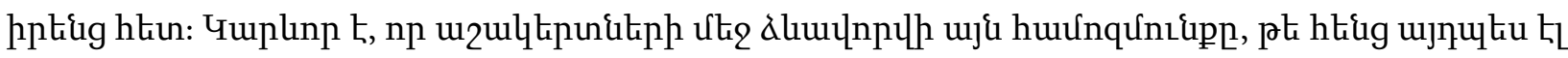

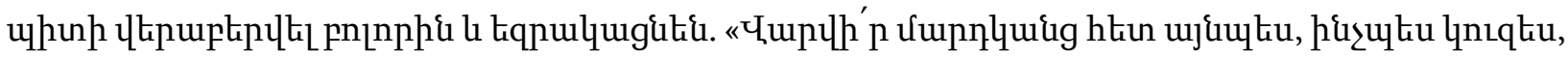
np \&puifp lthumptiplti ptiq»:

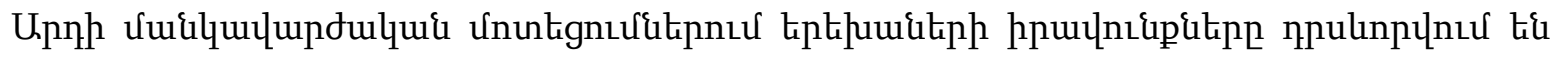

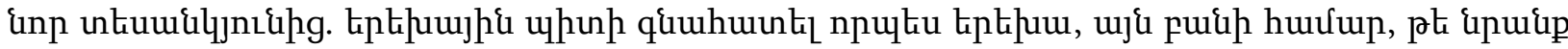

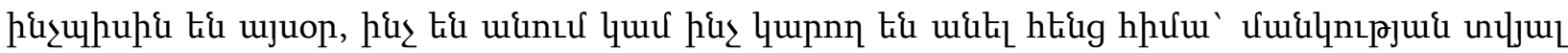

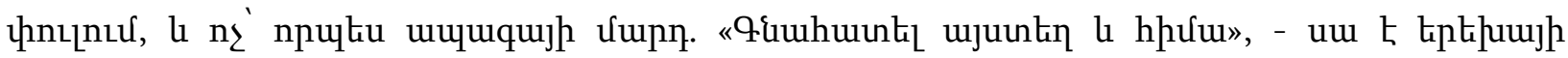

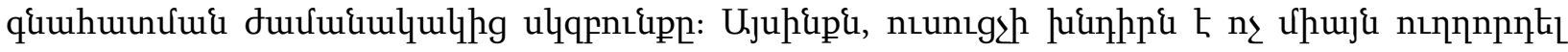

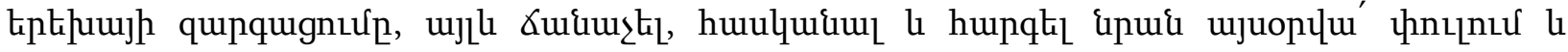

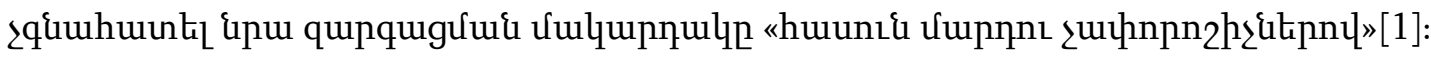

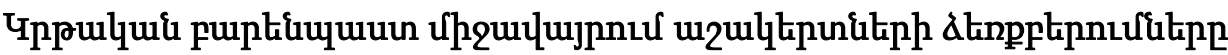




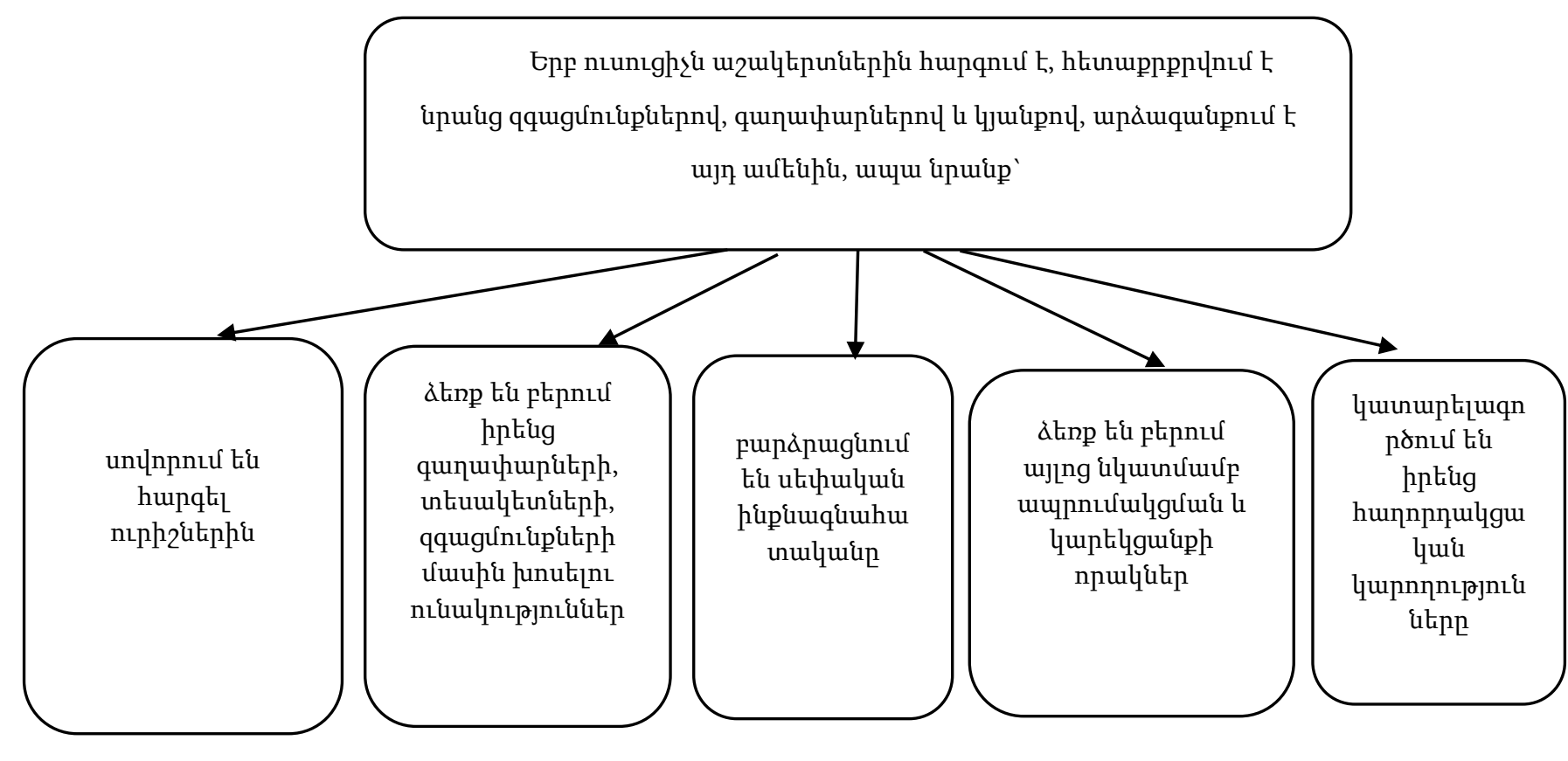

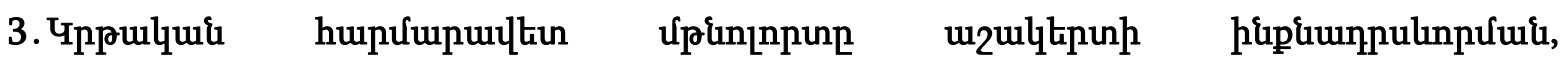

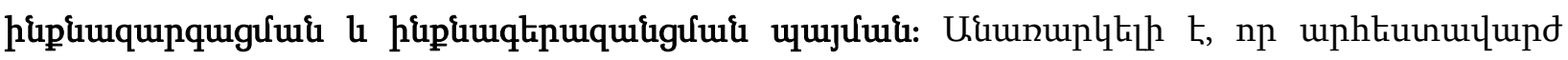

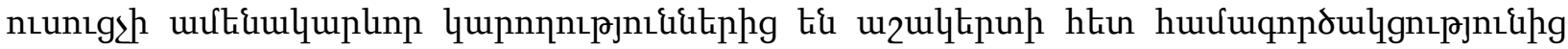

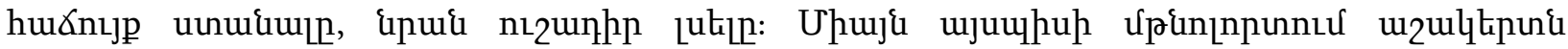

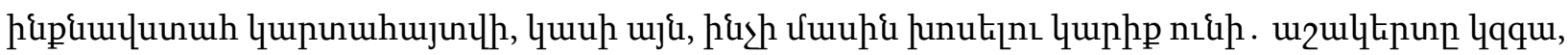

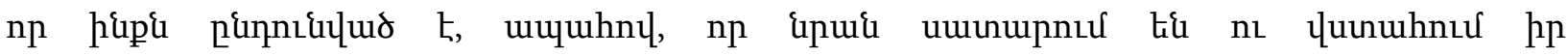

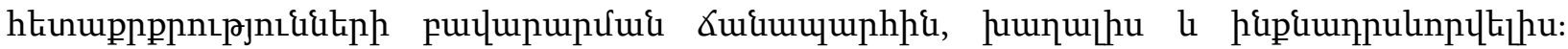

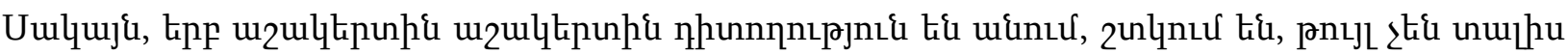

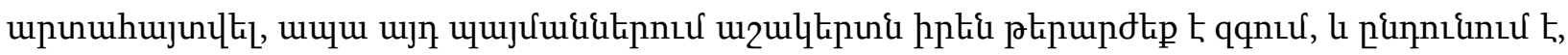

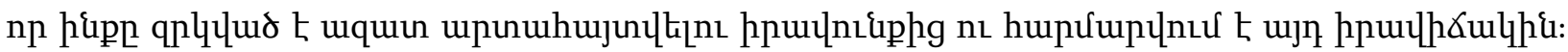

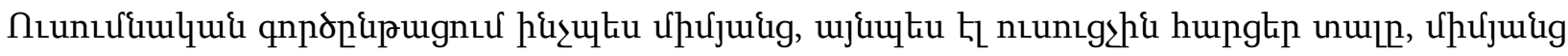

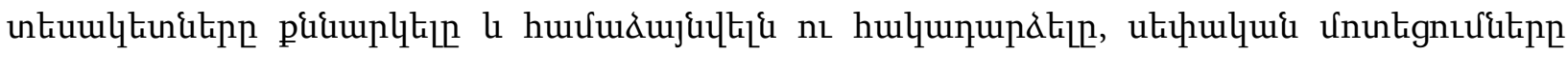

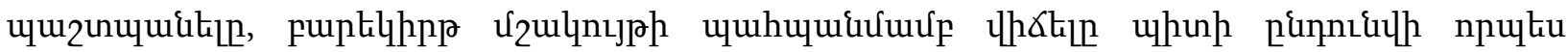

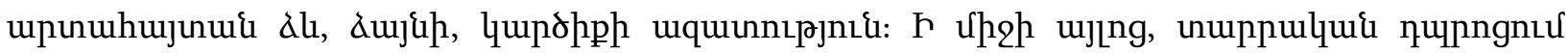

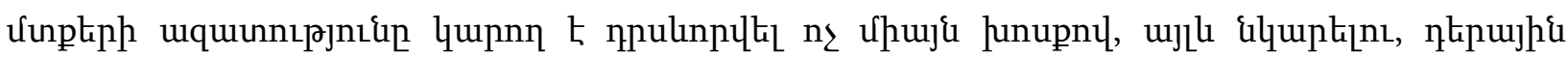

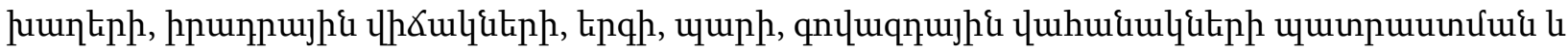

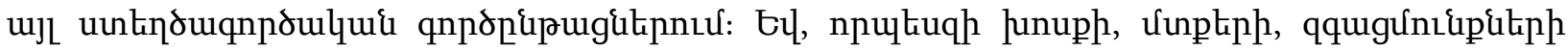

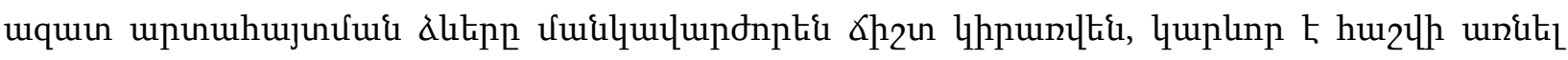

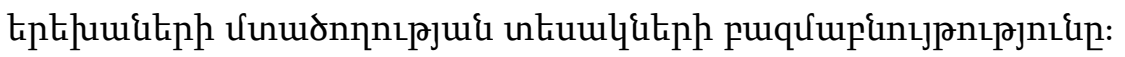




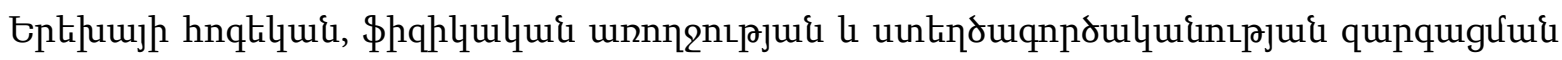

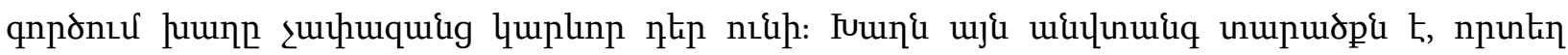

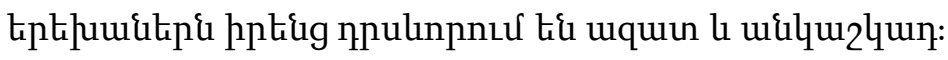

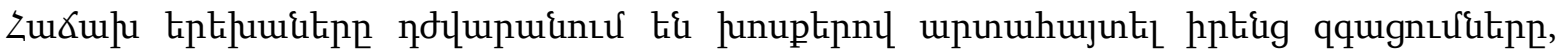

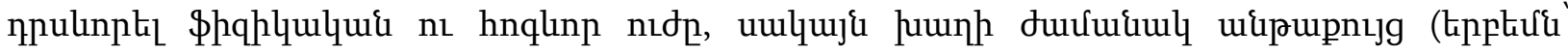

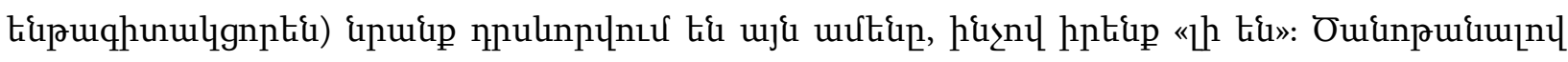

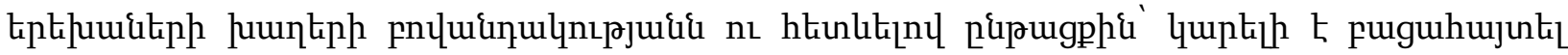

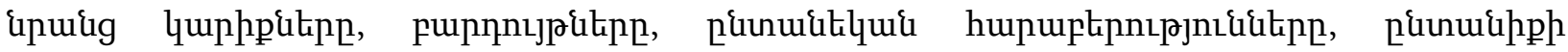

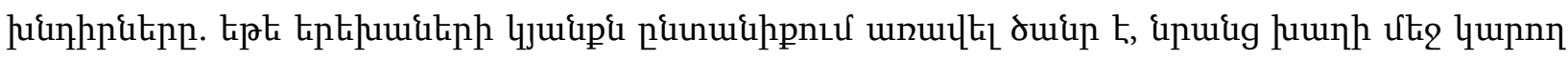

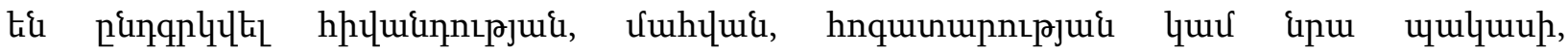

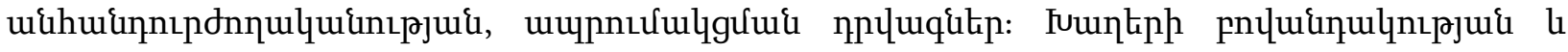

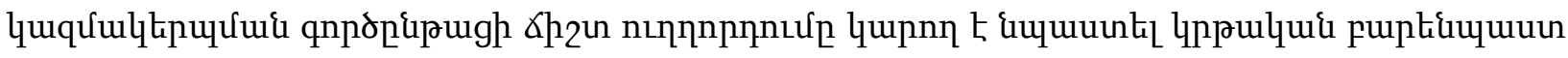

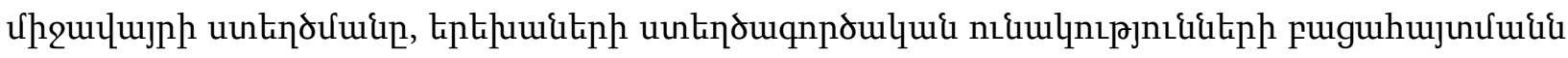
nı qunquarufuin:

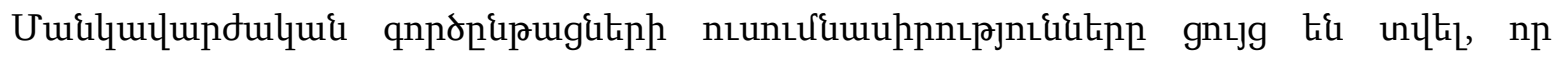

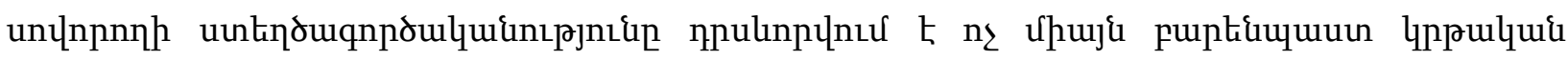

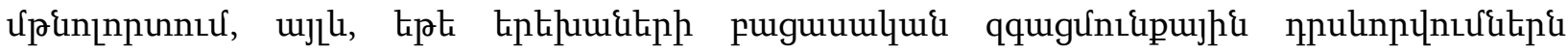

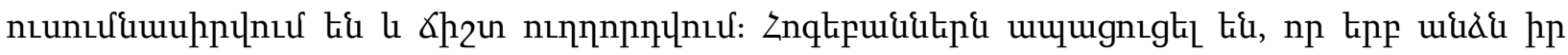

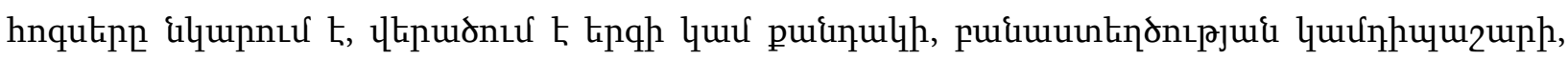

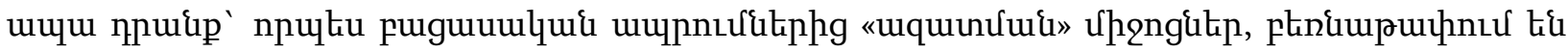

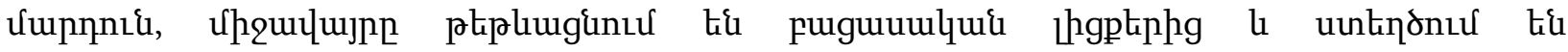

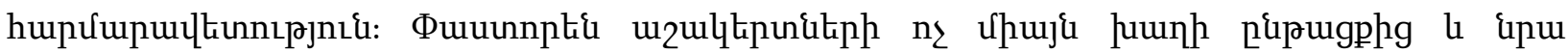

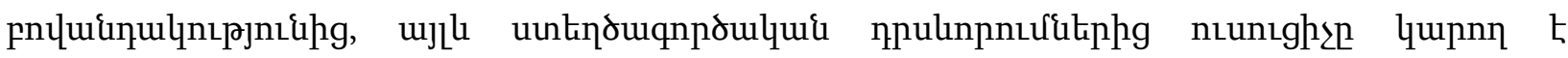

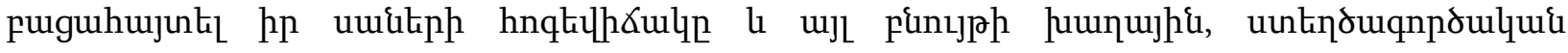

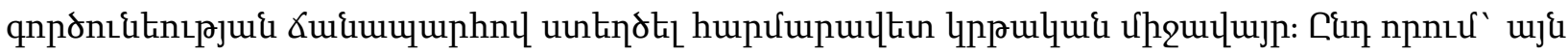

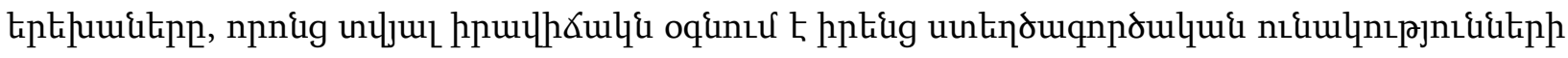

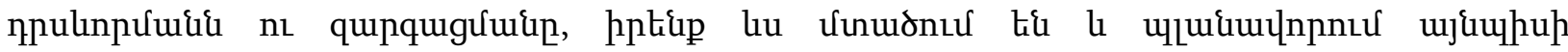

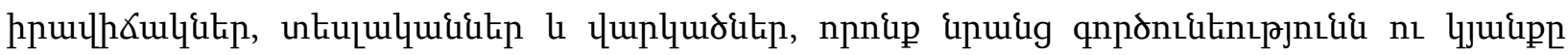

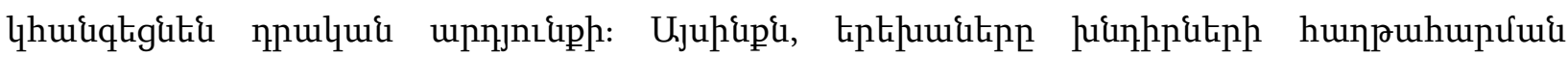

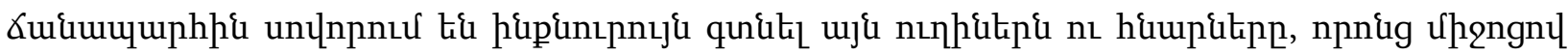

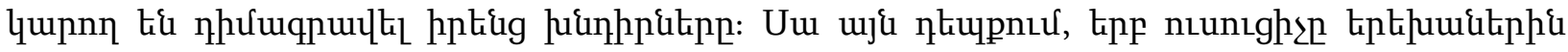

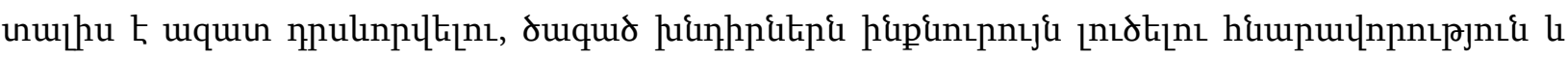

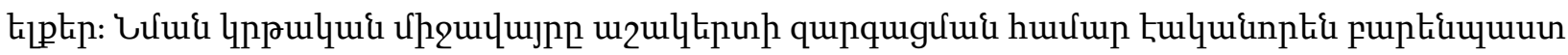


Ł, lu hupurupultin:

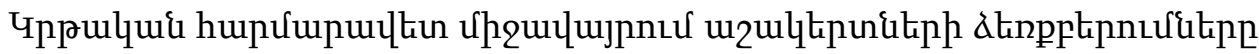

Epp nıunıgh

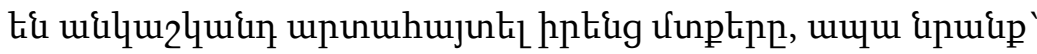

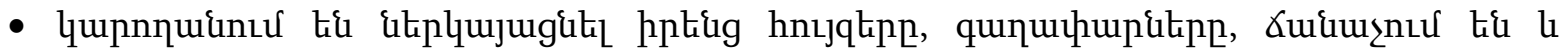

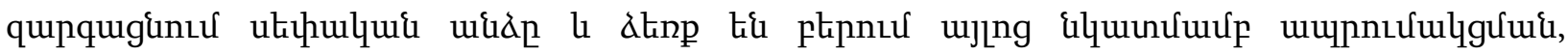
quptilighins npulquten,

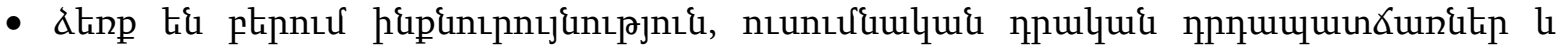

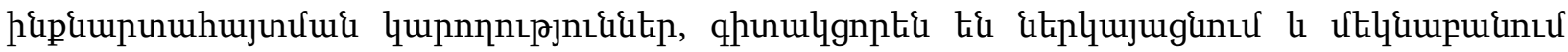
hptíg ltiquuuhnpàn,

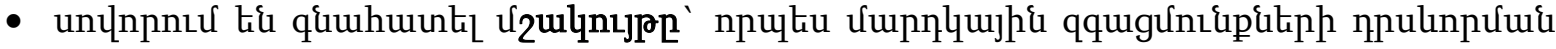

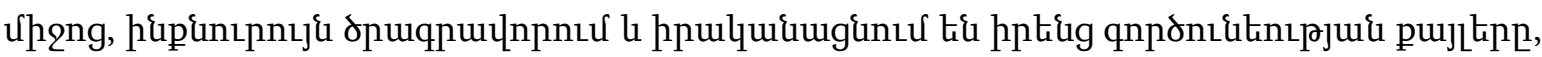

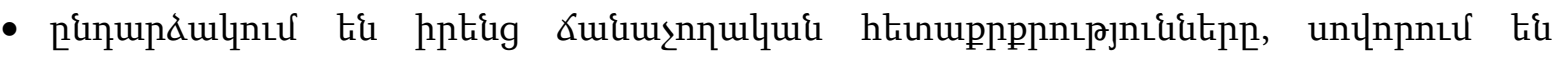

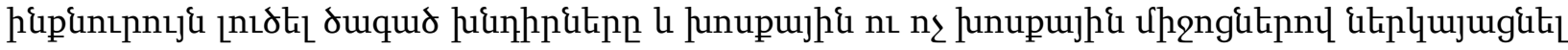

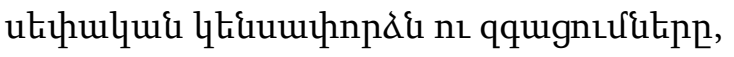

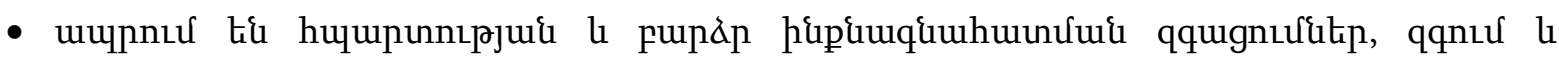

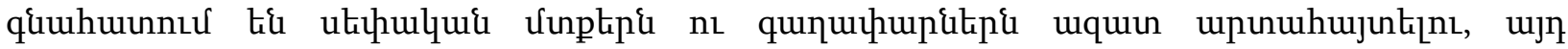

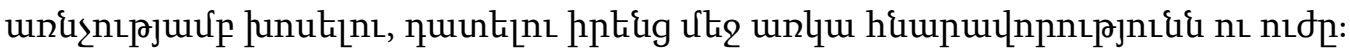

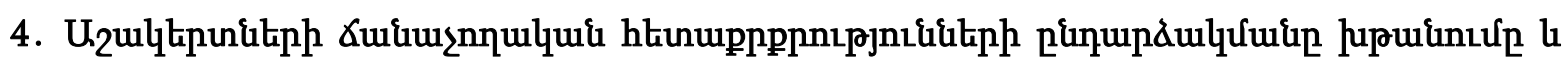

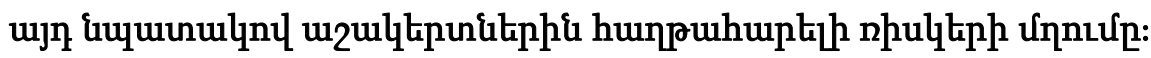

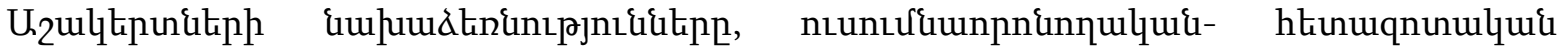

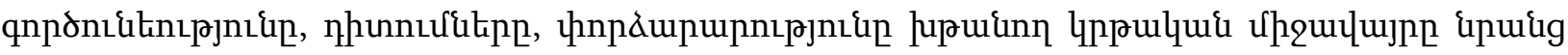

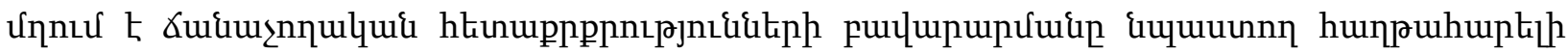

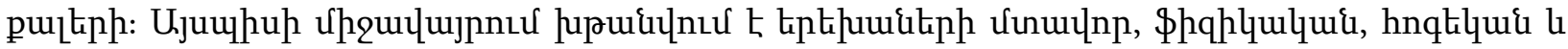

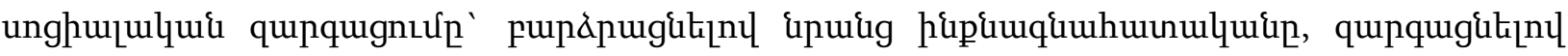

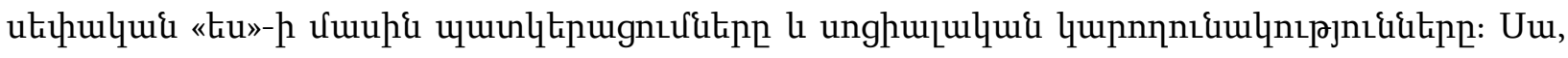

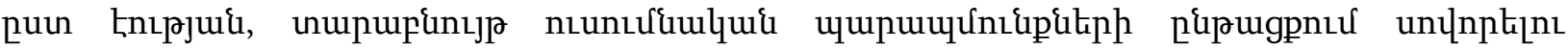

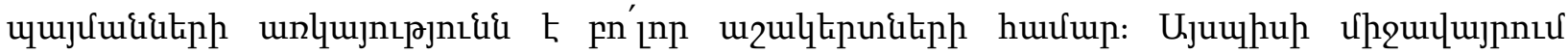

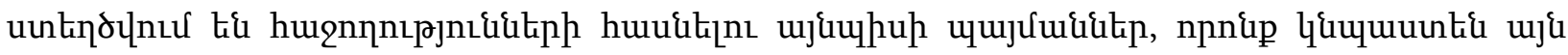

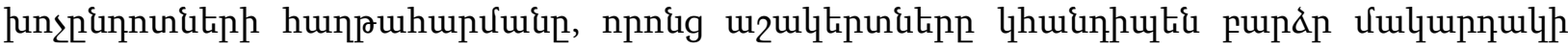

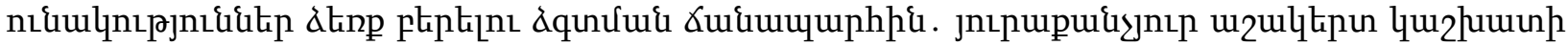

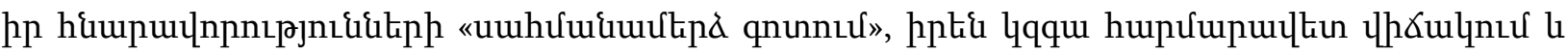

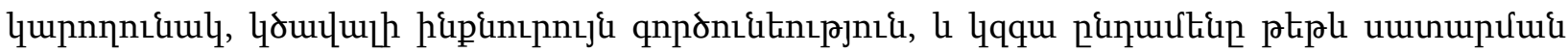




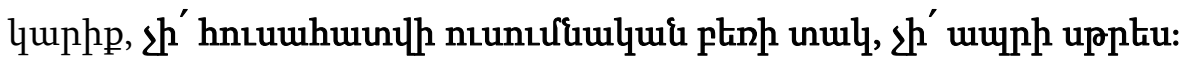

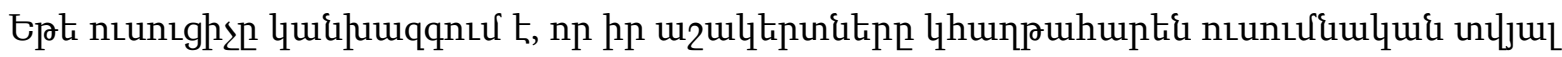

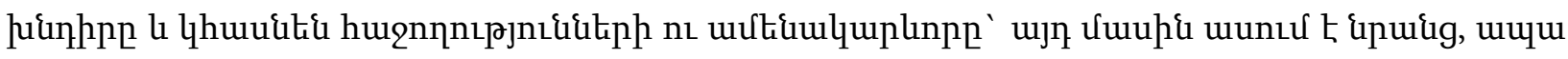

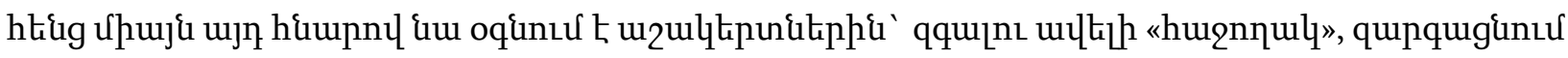

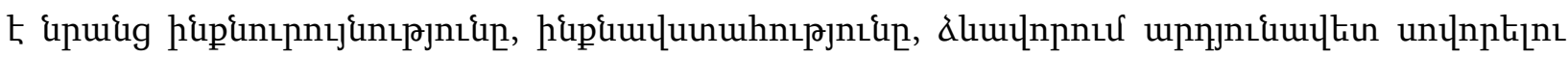

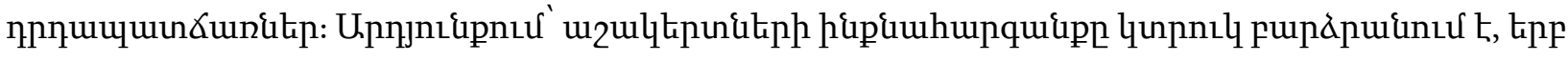

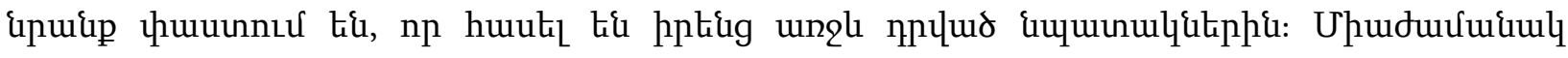

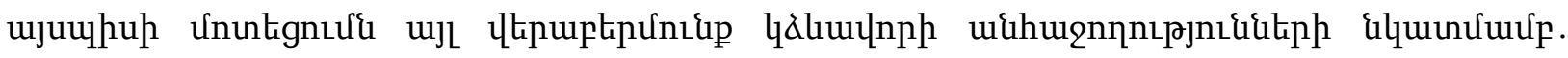

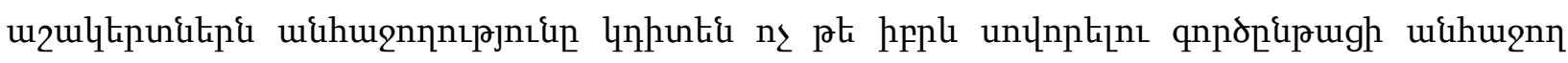

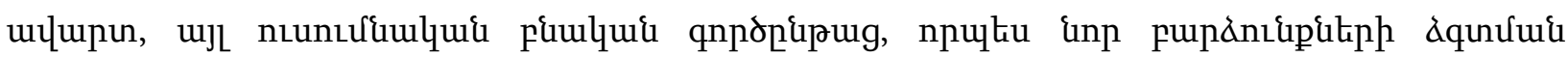

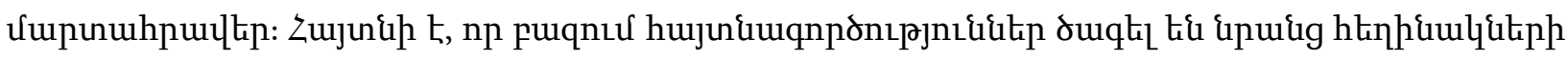

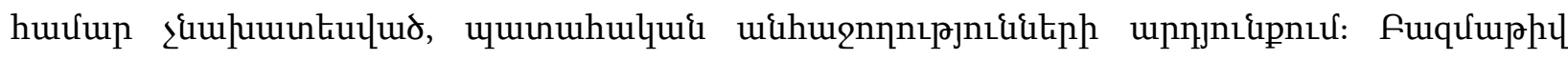

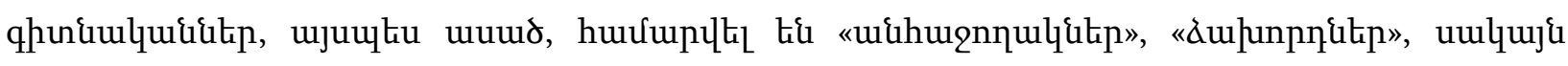

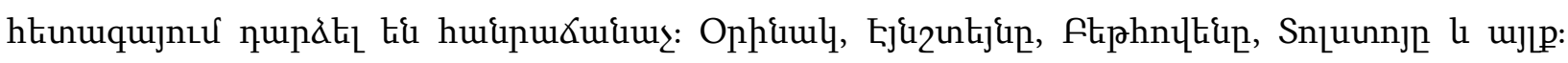

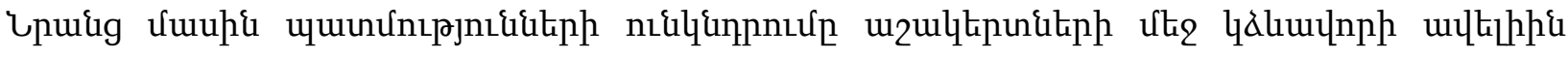

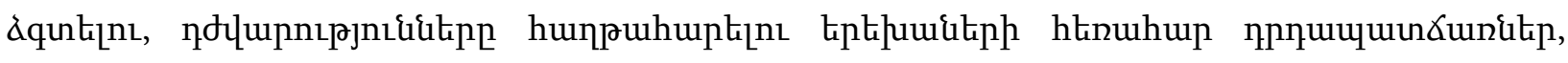

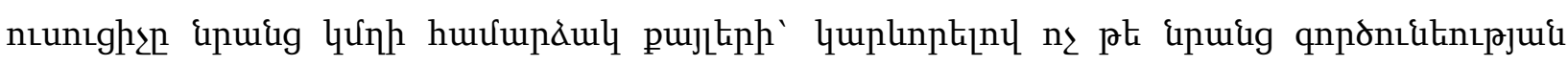

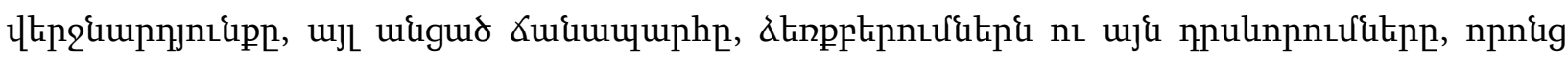

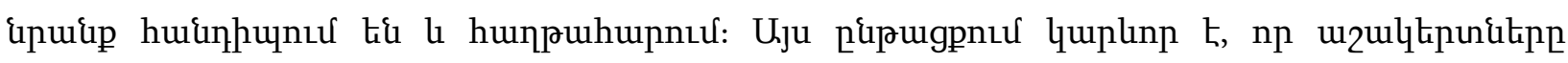

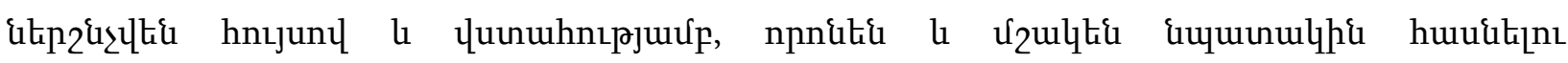

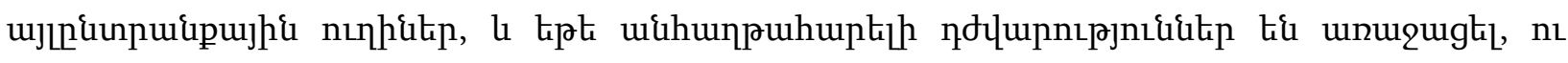

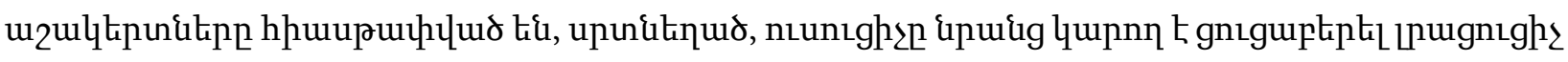

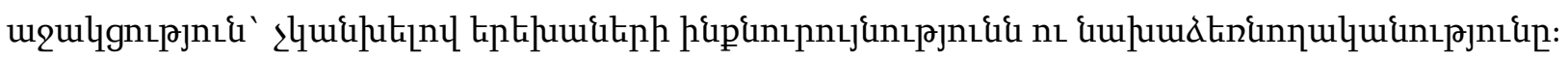

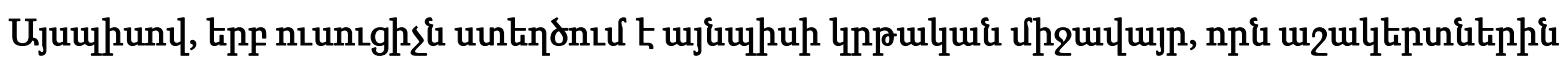

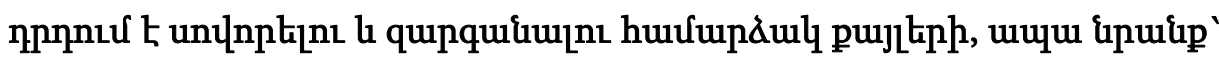

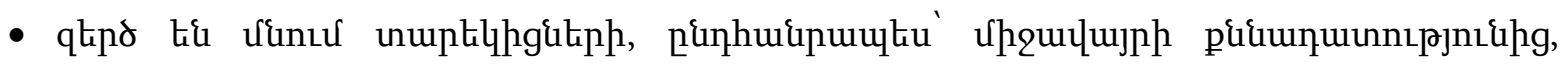

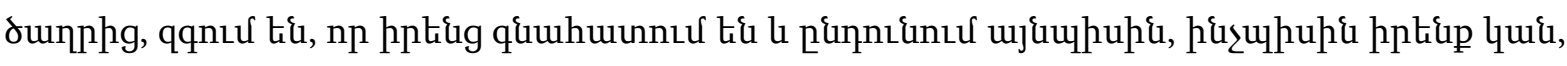

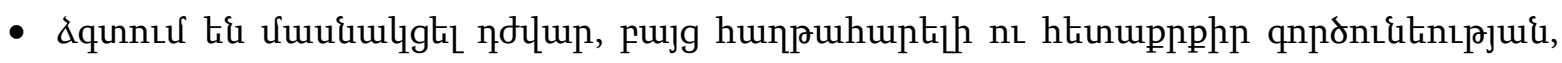

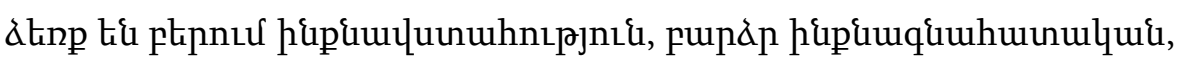

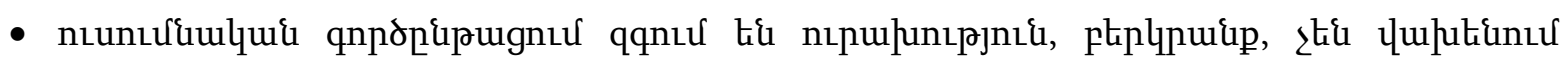

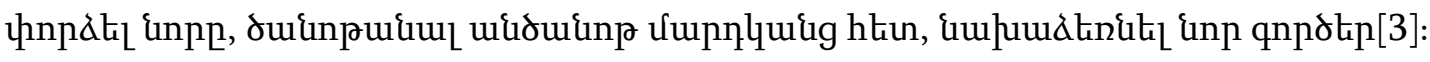

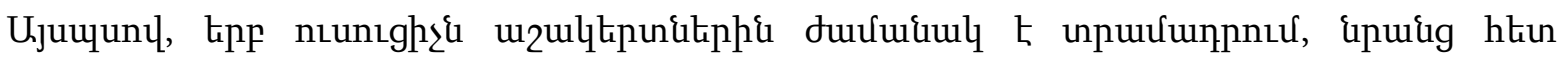

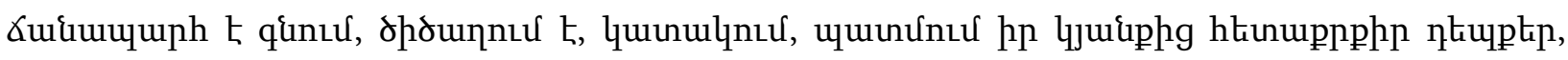




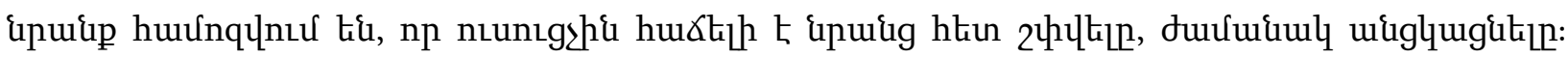

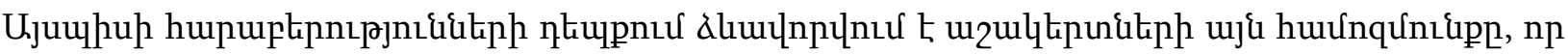

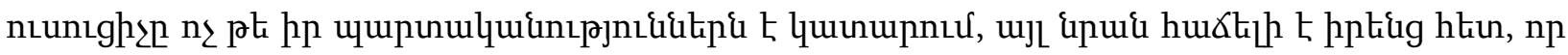

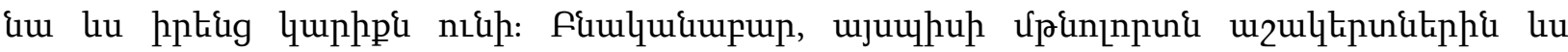
uqupnuulnptiginıu

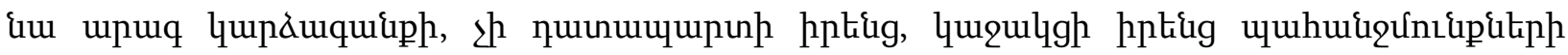

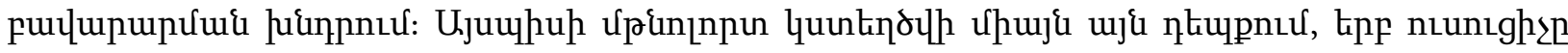

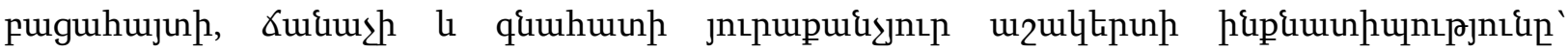

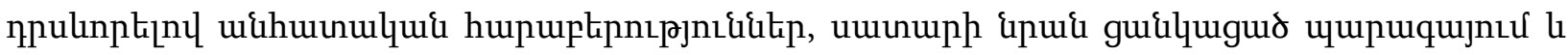

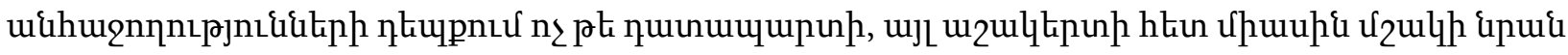

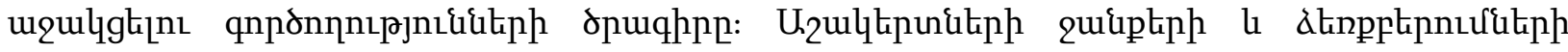

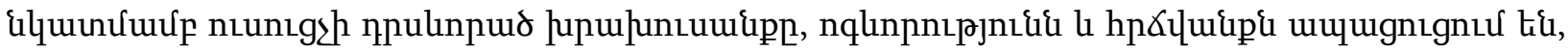

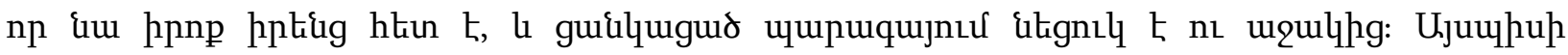

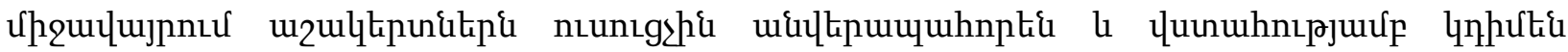

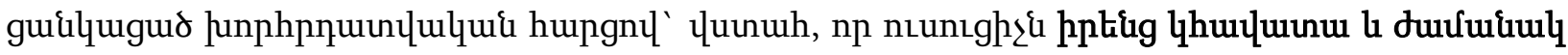

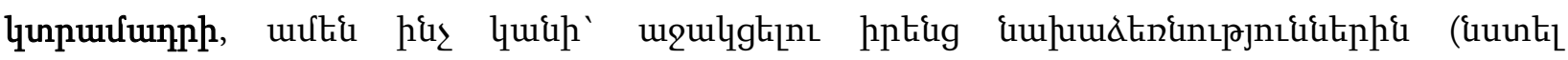

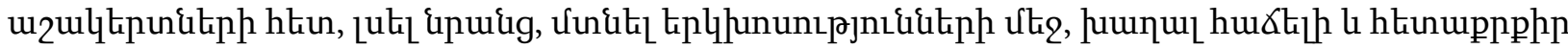

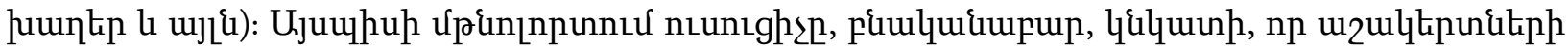

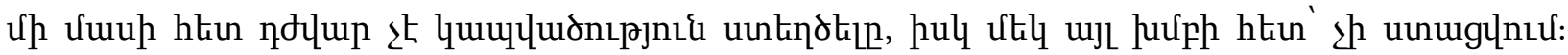

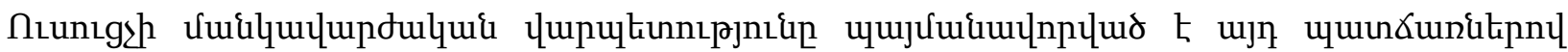

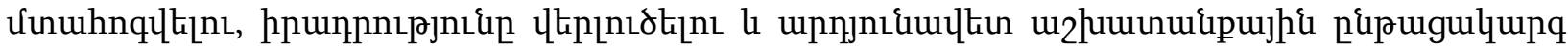

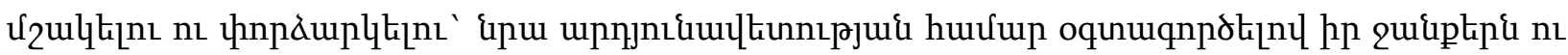

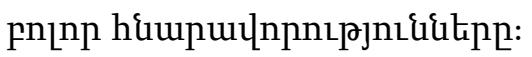

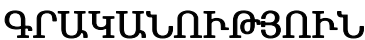

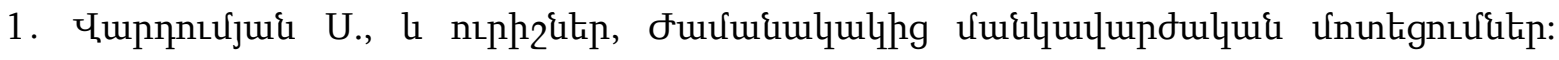

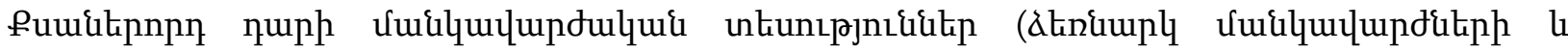
nıuuinnitiph hưưp), Epluwi, Ujptpu, 2005p. 407 kq

2. Бабаева И. А. Психологическая безопасность в образовании: монография, СПБ.: Изд-во „Союз”, 2002, 271 с.

3. Груздева Н.В. Методологические подходы к созданию образовательного пространства школы/ Образовательная среда школы: проблемы и перспективы развития / Матер. шестой научпракт. конф.- СПб, 2001 .- С. 30-34. 


\section{PUPILS' SATISFACTION AS A CONDITION OF ENVIRONMENTAL EDUCATION}

Pupils' basic demands are discussed in the article. The author substantiates that the educational environment will be comfortable only in case of satisfying those demands. The author has observed four groups of demands that are essential for pupils and has represented the main pedagogical environment for satisfying them.

Keywords: pupils' needs, comfortable learning environment, social group, non-competitive relationship, positive feeling, respect, empathy, compassion. 